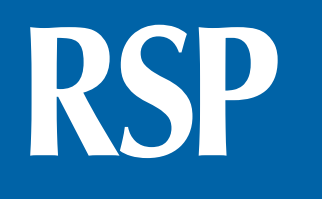

http://www.rsp.fsp.usp.br/

Revista de

Saúde Pública

\title{
High risk of respiratory diseases in children in the fire period in Western Amazon
}

Pãmela Rodrigues de Souza Silva', Eliane Ignotti", Beatriz Fátima Alves de Oliveira'"', Washington Leite Jungeriv, Fernando Morais ${ }^{\vee}$, Paulo Artaxov', Sandra Hacon"II

' Programa de Pós-Graduação em Saúde Coletiva. Instituto de Saúde Coletiva. Universidade Federal do Mato Grosso. Cuiabá, MT, Brasil

" Faculdade de Ciências da Saúde. Universidade do Estado de Mato Grosso. Cáceres, MT, Brasil

III Escola Nacional de Saúde Pública. Fundação Oswaldo Cruz. Rio de Janeiro, RJ, Brasil

iv Instituto de Medicina Social. Universidade Estadual do Rio de Janeiro. Rio de Janeiro, RJ, Brasil

v Instituto de Física. Universidade de São Paulo. São Paulo, SP, Brasil

\section{ABSTRACT}

OBJECTIVE: To analyze the toxicological risk of exposure to ozone $\left(\mathrm{O}_{3}\right)$ and fine particulate matter $\left(\mathrm{PM}_{2.5}\right)$ among schoolchildren..

METHODS: Toxicological risk assessment was used to evaluate the risk of exposure to $\mathrm{O}_{3}$ and $\mathrm{PM}_{2.5}$ from biomass burning among schoolchildren aged six to 14 years, residents of Rio Branco, Acre, Southern Amazon, Brazil. We used Monte Carlo simulation to estimate the potential intake dose of both pollutants.

RESULTS: During the slash-and-burn periods, $\mathrm{O}_{3}$ and $\mathrm{PM}_{2.5}$ concentrations reached $119.4 \mu \mathrm{g} / \mathrm{m}^{3}$ and $51.1 \mu \mathrm{g} / \mathrm{m}^{3}$,respectively. The schoolchildren incorporated medium potential doses regarding exposure to $\mathrm{O}_{3}\left(2.83 \mu \mathrm{g} / \mathrm{kg}\right.$.day, 95\%CI 2.72-2.94). For exposure to $\mathrm{PM}_{2.5}$, we did not find toxicological risk $(0.93 \mu \mathrm{g} / \mathrm{kg}$.day, $95 \% \mathrm{CI} 0.86-0.99)$. The toxicological risk for exposure to $\mathrm{O}_{3}$ was greater than 1 for all children $(\mathrm{QR}=2.75 ; 95 \% \mathrm{CI} 2.64-2.86)$.

CONCLUSIONS: Schoolchildren were exposed to high doses of $\mathrm{O}_{3}$ during the dry season of the region. This posed a toxicological risk, especially to those who had previous diseases.

DESCRIPTORS: Child. Respiratory Tract Diseases, epidemiology. Risk Factors. Ozone adverse, effects. Particulate Matter, adverse effects.

04328-040 São Paulo, SP, Brasil

E-mail: pam_r_s@hotmail.com

Received: 24 Jun 2014

Approved: 4 Aug 2015

How to cite: Silva PRS, Ignotti E, Oliveira BFA, Junger WL, Morais F, Artaxo P et al. High risk of respiratory diseases in children in the fire period in Western Amazon Rev Saude Publica. 2016;50:29.

Copyright: This is an open-access article distributed under the terms of the Creative Commons Attribution License, which permits unrestricted use, distribution, and reproduction in any medium, provided that the original author and source are credited. 
${ }^{a}$ World Health Organization. WHO Air quality guidelines for particulate matter, ozone, nitrogen dioxide and sulfur dioxide: globar update 2005: summary of risk assessment. Geneve: World Health

Organization; 2005

${ }^{b}$ Instituto Nacional de Pesquisas Espaciais. Portal de monitoramento de queimadas de incêndios. São Jose dos Campos (SP); 2012 [cited 2012 Oct 3]. Available from: http://www.inpe. br/queimadas

' Instituto Brasileiro de Geografia e Estatística. 2010. IBGE Cidades: Acre. Rio de Janeiro (RJ): Instituto Brasileiro de Geografia e Estatística; 2010 [cited 2011 Nov 7]. Available from: http://www.ibge.gov.br/ cidadesat/topwindow.htm?1

d U.S. Environmental Protection Agency. Risk assessment guidance for superfund. Vol 1, Human health evaluation manual (Part A): interim final. Washington (DC): U.S. Environmental Protection Agency; 1989. (EPA 540/1-89/003).

e Agency for Toxic Substances and Disease Registry. Public health assessment guidance manual: update. Atlanta: Agency for Toxic Substances and Disease Registry; 2005 [cited 2011 July 1]. Available from: http://www.atsdr.cdc.gov/ hac/PHAManual/PDFs/PHAGM final1-27-05.pdf

${ }^{\mathrm{f}}$ U.S. Environmental Protection Agency. Air quality management: National Ambient Air Quality Standards (NAAQS) for criteria pollutants. Washington (DC): U.S. Environmental Protection Agency; 2010a [cited 2012 Jun 15].

Available from: http://www.epa. gov/apti/course422/apc4a.html

\section{INTRODUCTION}

Ozone $\left(\mathrm{O}_{3}\right)$ and fine particulate matter $\left(\mathrm{PM}_{2.5}\right)$ are the pollutants with the greatest impact on public health, even at low concentrations ${ }^{\text {a }}$. Annually, approximately 0.7 million deaths by respiratory disease and 3.5 million deaths by cardiopulmonary disease worldwide are attributed to exposure to $\mathrm{O}_{3}$ and $\mathrm{PM}_{2.5}$, respectively, originating from anthropogenic activities ${ }^{1}$.

Since $\mathrm{O}_{3}$ reaches the lower airways of children, its oxidizing and cytotoxic properties decrease their pulmonary function ${ }^{7}$. Several studies have also showed that exposure to $\mathrm{PM}_{2.5}$ is an important risk factor for health, especially for cardiopulmonary diseases ${ }^{15}$, even when $\mathrm{PM}_{2.5}$ derived from biomass burning $g^{8-10,13,14}$.

In the Amazon region of Brazil, high peaks of atmospheric pollution occur during the dry season. Intense slash-and-burn has been observed in the last few years in Rio Branco, AC, exposing the local population to high levels of atmospheric pollution ${ }^{\mathrm{b}}$.

Monitoring pollutants at soil level is crucial to observe the effects of exposure on human health, especially in children and older adults. The number of monitoring networks in Brazil is growing, but there is no monitoring network in the Amazon region to continuously oversee the main pollutants, even though this region has gained international attention due to its significant amount of pollutants.

The aim of this study was to analyze the toxicological risk of exposure to $\mathrm{O}_{3}$ and $\mathrm{PM}_{2.5}$ among schoolchildren.

\section{METHODS}

\section{Study Design}

This study is a risk assessment in which we estimated the potential intake dose and the toxicological risk of the pollutants $\mathrm{O}_{3}$ and $\mathrm{PM}_{2.5}$ for children aged six to 14 years. This study assessed the risk of exposure to $\mathrm{O}_{3}$ and $\mathrm{PM}_{2.5}$ located in an area of biomass burning activities in the Brazilian Amazon. We conducted this study in Rio Branco (the largest city in Acre state, with 336,038 inhabitants $^{\mathrm{c}}$ ) between August and October, 2009, during the dry season ${ }^{\mathrm{b}}$. The United States Environmental Protection Agency (EPA) ${ }^{\mathrm{d}}$ and the Agency for Toxic Substances and Disease Register ${ }^{e}$ methodologies were used to assess toxicological risk, adapted to estimate the potential intake dose of $\mathrm{O}_{3}$ and $\mathrm{PM}_{2.5}$ pollutants.

\section{Study Area and Population}

According to education officials in Rio Branco, the public school assessed had similar demographic features as the local population. The school is in the same area as Horto Florestal (approximately 870 meters away), where $\mathrm{PM}_{2.5}$ and $\mathrm{O}_{3}$ were hourly measured. The advantage of this location is less traffic in its surroundings when compared with the downtown. It is also in the opposite direction to the industrial area of the city, with mainly brick factories, which prevents interference from pollutants from other sources.

A continuous air quality monitoring station was established and supervised by the atmospheric pollution study group of Instituto de Física of Universidade de São Paulo. Missing data were not attributed for days when monitoring failed.

The $\mathrm{O}_{3}$ concentrations were measured by a $2 \mathrm{~B}$ Tech $\mathrm{O}_{3}$ monitor installed along with other air quality samplers at a height of five meters. This monitor meets the technical $\mathrm{O}_{3}$ measurement recommendations of the $\mathrm{EPA}^{\mathrm{f}}$ and measured all concentrations of $\mathrm{O}_{3}$ every day in hourly intervals. Then, we estimated the average of the eight hours with the greatest $\mathrm{O}_{3}$ concentrations throughout the day, which usually occurred between 12 and 20 hours. 
The $\mathrm{PM}_{2.5}$ concentrations were estimated based on real time measurements of the $\mathrm{PM}_{10}$ (combination of coarse and fine particulate matter) mass applied to the daily ratio of $\mathrm{PM}_{2.5(\mathrm{FCS})} / \mathrm{PM}_{10(\mathrm{FCS})}$. Hourly, $\mathrm{PM}_{10}$ levels were measured by a Tapered Element Oscillating Monitor (TEOM), and $\mathrm{PM}_{2.5}$ concentrations were obtained by a Fine and Coarse Particulate Matter Sampler (FCS), collected by inertial impaction in $47 \mathrm{~mm}$ polycarbonate filters with $4 \mu \mathrm{m}$ diameter pores. Daily averages were estimated based on the $\mathrm{PM}_{2.5}$ concentrations that were measured every day in hourly intervals, from 12 a.m. to 11 p.m. The lognormal distribution fits the model best.

Among the 250 children randomly selected from the sample, 237 (95.0\%) agreed to participate in the study.

\section{Study Variables}

The variables sex, age, and asthma were provided in an individual survey with the children's parents or guardians. The survey was conducted by duly qualified research assistants. Eight questions specifically addressed asthma symptoms, which were related to wheezing, shortness of breath, and coughing, according to the method of the International Study of Asthma and Allergies in Childhood ${ }^{g}$.

The children's weight and height were obtained in a single measurement at the beginning of the study. Project researchers used a mechanical anthropometric scale with a ruler.

The potential $\mathrm{O}_{3}$ and $\mathrm{PM}_{2.5}$ intake dose was estimated for all schoolchildren. The participants were separated into groups stratified by age, sex, presence of asthma, and body mass index (BMI). The average of the eight hours with the greatest $\mathrm{O}_{3}$ concentration and the average of daily $\mathrm{PM}_{25}$ concentrations were compared among the groups. The equation to estimate the daily potential intake dose and the toxicological risk of $\mathrm{O}_{3}$ and $\mathrm{PM}_{2.5}$ followed the general EPA equation ${ }^{11}$ described below:

Potential Intake Dose:

$$
\mathrm{I}=\mathrm{C}_{\mathrm{A}} \frac{\mathrm{IP} \times \mathrm{FR} \times \mathrm{FA} \times \mathrm{ET} \times \mathrm{EF} \times \mathrm{ED}}{\mathrm{BW}} \times \frac{1}{\mathrm{AT}}
$$

In which:

$\mathrm{I}=$ pollutant intake dose $(\mu \mathrm{g} / \mathrm{kg}$.day);

$\mathrm{C}_{\mathrm{A}}=$ average $\mathrm{O}_{3}$ and $\mathrm{PM}_{2.5}$ concentrations from August to October, $2009\left(\mu \mathrm{g} / \mathrm{m}^{3}\right)$;

IP = inhalation rate of the exposed group $\left(\mathrm{m}^{3} / \mathrm{d}\right)$ :

Inhalation rates were obtained from the study conducted by Brochu et al. ${ }^{2}$, following EPA ${ }^{\mathrm{d}}$ recommendations. Values for the subjects' daily inhalation rate $\left(\mu \mathrm{g} / \mathrm{kg}\right.$.day), observed in the $95^{\text {th }}$ percentile, were used and applied to the children's body weight, adjusted by age, sex, and BMI.

$\mathrm{FR}=$ retention factor:

We assumed a retention factor of $\mathrm{FR}=1$, which represents the highest exposure and the highest potential impact on subjects' health.

$\mathrm{FA}=$ absorption factor:

We assumed an absorption factor of $\mathrm{FA}=1$, which represents the highest exposure and the highest potential impact on subjects' health.

$\mathrm{ET}=$ exposure time $(\mathrm{h} / \mathrm{d})$ :

ISAAC. 2011 lcited 2011 Nov

2]. Available from: http://isaac.

auckland.ac.nz/index.html

The schoolchildren's exposure time to $\mathrm{O}_{3}$ totaled eight hours. According to studies conducted in the region, the highest $\mathrm{O}_{3}$ concentration occurs during times of higher ultraviolet 
radiation ${ }^{16}$. Therefore, we assumed the occurrence of constant exposure. According to the $\mathrm{EPA}^{16}$, the measurement of an individual's exposure to $\mathrm{O}_{3}$ is normally conducted throughout the exposure period.

The schoolchildren's exposure time to $\mathrm{PM}_{2.5}$ ranged from two to eight hours. This corresponds to the period when children are outdoors, according to recommendations in the Highlights of the Child-Specific Exposure Factors Handbook. ${ }^{\text {h }}$ We did not select this exposure time according to its daily variation because the concentration of $\mathrm{PM}_{2.5}$, in contrast to $\mathrm{O}_{3}$, can vary throughout the day and is independent of ultraviolet radiation ${ }^{i}$. Therefore, we assumed the exposure to this pollutant was uniform for each 24-hour period.

$\mathrm{EF}=$ exposure frequency $(\mathrm{d} / \mathrm{y}):$

The $\mathrm{O}_{3}$ and $\mathrm{PM}_{2.5}$ concentrations were monitored for 68 and 80 days, respectively.

$\mathrm{ED}=$ duration of exposure $(\mathrm{y})$ :

The period from July to December corresponds to half a year, including 182 days. The 2009 dry season in the region lasted for 122 days, which corresponded to the average exposure time. Therefore, the duration of exposure equaled $122 / 182=0.67$.

BW = body weight $(\mathrm{kg})$;

$\mathrm{AT}=$ average time, period of exposure in which the dose was measured (d):

The average exposure time was 122 days, which corresponds to the longest dry period in the region being studied in 2009 .

We assumed a constant distribution for the variables average time, duration of exposure, frequency of exposure, and exposure time for $\mathrm{O}_{3}$.

Toxicological Risk:

$$
\mathrm{RQ} \frac{\mathrm{I}}{\mathrm{RfD}}
$$

In which:

$\mathrm{RQ}=$ risk quotient;

Risk quotients are classified as follows: $R Q \leq 1$ : unlikely risk, even in population groups that are sensitive to adverse health effects; $R Q>1$ : there is a risk of non-carcinogenic adverse effects on human health.

$\mathrm{I}=$ potential intake dose $(\mu \mathrm{g} / \mathrm{kg}$.day);

RfD: reference dose for each pollutant;

We estimated each pollutant's RfD in this study in $\mu \mathrm{g} / \mathrm{kg}$.day units to compare them with the potential intake dose estimated in the exposure assessment. To achieve this, we applied the RfD in the potential intake dose equation above, with average inhalation rates and body weights of all children and environmental variables $\left(\mathrm{PM}_{2.5}\right.$ and $\left.\mathrm{O}_{3}\right)$ of the location being studied ${ }^{2, \mathrm{~d}}$.

h U.S. Environmental Protection Agency. Highlights of the child-specific exposure factors handbook. North Carolina: U.S. Environmental Protection Agency; 2009. (EPA/600/R-08/135).

i U.S. Environmental Protection Agency. Quantitative health risk assessment for particulate matter. North Carolina: U.S. Environmental Protection Agency; 2010b. (EPA-452/R-10-005).

According to Collins et al. ${ }^{3}$ and McDonnell et al. ${ }^{12}$, the estimated $\mathrm{RfD}$ for $\mathrm{O}_{3}$ was obtained assuming the lowest-observed-adverse-effect level (LOAEL) that matches the lowest pollutant dose that may cause observed side effects on human health, including sensitive groups, over a given time of exposure. Studies have found a relationship in which healthy adults and children exposed to $0.12 \mathrm{ppm}_{\mathrm{p}} \mathrm{O}_{3}$ experienced reduced pulmonary function for a one-hour exposure. Expanding the data to the intraspecies uncertainty factor, which was 10, from no-observed-adverse-effect level (NOAEL) to LOAEL, which was 10, resulted in an estimated level of $18.80 \mu \mathrm{g} / \mathrm{m}^{3}$. 
In contrast, to obtain RfD for $\mathrm{PM}_{2.5}$, we used NOAEL, which corresponds to the maximum dose without any noticeable adverse effects on human health, corresponding to $5.8 \mu \mathrm{g} / \mathrm{m}^{3 \mathrm{i}}$. For $\mathrm{PM}_{2.5}$ exposures above $5.8 \mu \mathrm{g} / \mathrm{m}^{3}$, we observed an estimated risk of mortality caused by respiratory diseases.

\section{Statistical Analysis}

Monte Carlo simulations were used to estimate the potential intake dose in the different subgroups of children for both pollutants being studied. Probabilistic models were used to assess dose by the general equation of the potential dose. The probability distributions for each input model variable were defined after a descriptive analysis and by the adhesion Kolmogorov-Smirnov test results. The input model variables and the assumed probability distributions are presented in Table 1. We estimated average $\mathrm{O}_{3}$ and $\mathrm{PM}_{2.5}$ doses according to individual characteristics of schoolchildren, by 1,000 simulations for each category under analysis. In the group of schoolchildren, differences between averages of $\mathrm{O}_{3}$ and $\mathrm{PM}_{2.5}$ doses for each category under study were compared using $\mathrm{t}$ student and ANOVA tests when appropriate, at a significance level of $5 \%(95 \% \mathrm{CI})$. Model entry variables with the most influence in estimating the dose were identified by Spearman correlation coefficients. Application R 2.13 was used in simulations and statistical analyses.

Table 1. Description of variables entered in the exposure model for inhalation rate and body weight, according to an eight-hour $\mathrm{O}_{3}$ average and daily $\mathrm{PM}_{2.5}$ average.

\begin{tabular}{|c|c|c|c|c|c|c|}
\hline Entry variables & $\mathbf{n}$ & Average & SD & Minimum & Maximum & Distribution \\
\hline \multicolumn{7}{|c|}{ Inhalation rate $\left(\mathrm{m}^{3} / \mathrm{d}\right)$} \\
\hline \multicolumn{7}{|c|}{ Age $(y)$} \\
\hline $6-8 y$ & 57 & 12.18 & 2.43 & 8.64 & 19.99 & Log-normal \\
\hline $9-11 y$ & 83 & 14.58 & 2.62 & 8.01 & 24.72 & Log-normal \\
\hline $12-14 y$ & 97 & 18.75 & 3.58 & 12.90 & 28.92 & Log-normal \\
\hline \multicolumn{7}{|l|}{ Sex } \\
\hline Male & 113 & 15.99 & 4.26 & 8.64 & 28.92 & Log-normal \\
\hline Female & 124 & 15.45 & 3.81 & 8.01 & 24.48 & Log-normal \\
\hline \multicolumn{7}{|l|}{ Asthma } \\
\hline Yes & 45 & 15.42 & 4.71 & 9.28 & 25.81 & Log-normal \\
\hline No & 192 & 15.78 & 3.86 & 8.01 & 28.92 & Log-normal \\
\hline \multicolumn{7}{|l|}{ BMI } \\
\hline Healthy & 221 & 15.41 & 3.91 & 8.01 & 28.92 & Log-normal \\
\hline Overweight & 16 & 19.79 & 3.49 & 14.76 & 25.70 & Log-normal \\
\hline Total & 237 & 15.71 & 4.03 & 8.01 & 28.92 & Log-normal \\
\hline \multicolumn{7}{|l|}{ Body weight (kg) } \\
\hline \multicolumn{7}{|l|}{ Age } \\
\hline $6-8 y$ & 57 & 23.07 & 4.53 & 16.00 & 38.00 & Log-normal \\
\hline $9-11 y$ & 83 & 32.77 & 7.33 & 19.00 & 56.00 & Log-normal \\
\hline $12-14 y$ & 97 & 44.04 & 9.28 & 29.00 & 72.00 & Log-normal \\
\hline \multicolumn{7}{|l|}{ Sex } \\
\hline Male & 113 & 34.46 & 11.32 & 16.00 & 72.00 & Log-normal \\
\hline Female & 124 & 35.59 & 11.35 & 17.00 & 67.00 & Log-normal \\
\hline \multicolumn{7}{|l|}{ Asthma } \\
\hline Yes & 45 & 33.69 & 12.67 & 18.00 & 65.00 & Log-normal \\
\hline No & 192 & 35.37 & 11.00 & 16.00 & 72.00 & Log-normal \\
\hline \multicolumn{7}{|l|}{$\mathrm{BMI}$} \\
\hline Healthy & 221 & 33.83 & 10.37 & 16.00 & 65.00 & Log-normal \\
\hline Overweight & 16 & 51.94 & 10.76 & 36.00 & 72.00 & Log-normal \\
\hline Total & 237 & 35.05 & 11.32 & 16.00 & 72.00 & Log-normal \\
\hline
\end{tabular}

BMI: body mass index; $\mathrm{O}_{3}$ : ozone; $\mathrm{PM}_{2.5}$ : fine particulate matter. 


\section{Ethical Aspects}

This study was approved by the Ethics Committee of the National School of Public Health (CEP/ESNP/FIOCRUZ - Protocol 25/07 - on March 7, 2007). The children's parents or guardians signed an informed consent form.

\section{RESULTS}

The highest $\mathrm{O}_{3}$ concentrations were recorded in December with two peaks over $100 \mu \mathrm{g} / \mathrm{m}^{3}$, which exceeds the air quality standard levels prescribed by the WHO. It did not rain on those days, and relative humidity was $76.0 \%$ and $80.0 \%$ (Figure 1).

The daily average $\mathrm{PM}_{2.5}$ concentration was high, with figures during September that were above the air quality recommendations prescribed by the EPA. The concentrations were $43.6 \mu \mathrm{g} / \mathrm{m}^{3}$ on August 15, 2009; $51.1 \mu \mathrm{g} / \mathrm{m}^{3}$ on September 14, 2009; and $45.7 \mu \mathrm{g} / \mathrm{m}^{3}$ on September 15, 2009. On these days, relative humidity levels were $60.0 \%, 80.0 \%$, and $73.0 \%$, respectively (Figure 2).

The lognormal probability distribution was used to simulate the concentration, inhalation rate, and body weight of schoolchildren with the results of the adhesion Kolmogorov-Smirnov test placed in the best fit for the data. The uniform probability distribution was assumed for exposure time (ET) while the exposure frequency (EF), duration (ED), and average time (AT) were maintained constant in the model (Table 1).

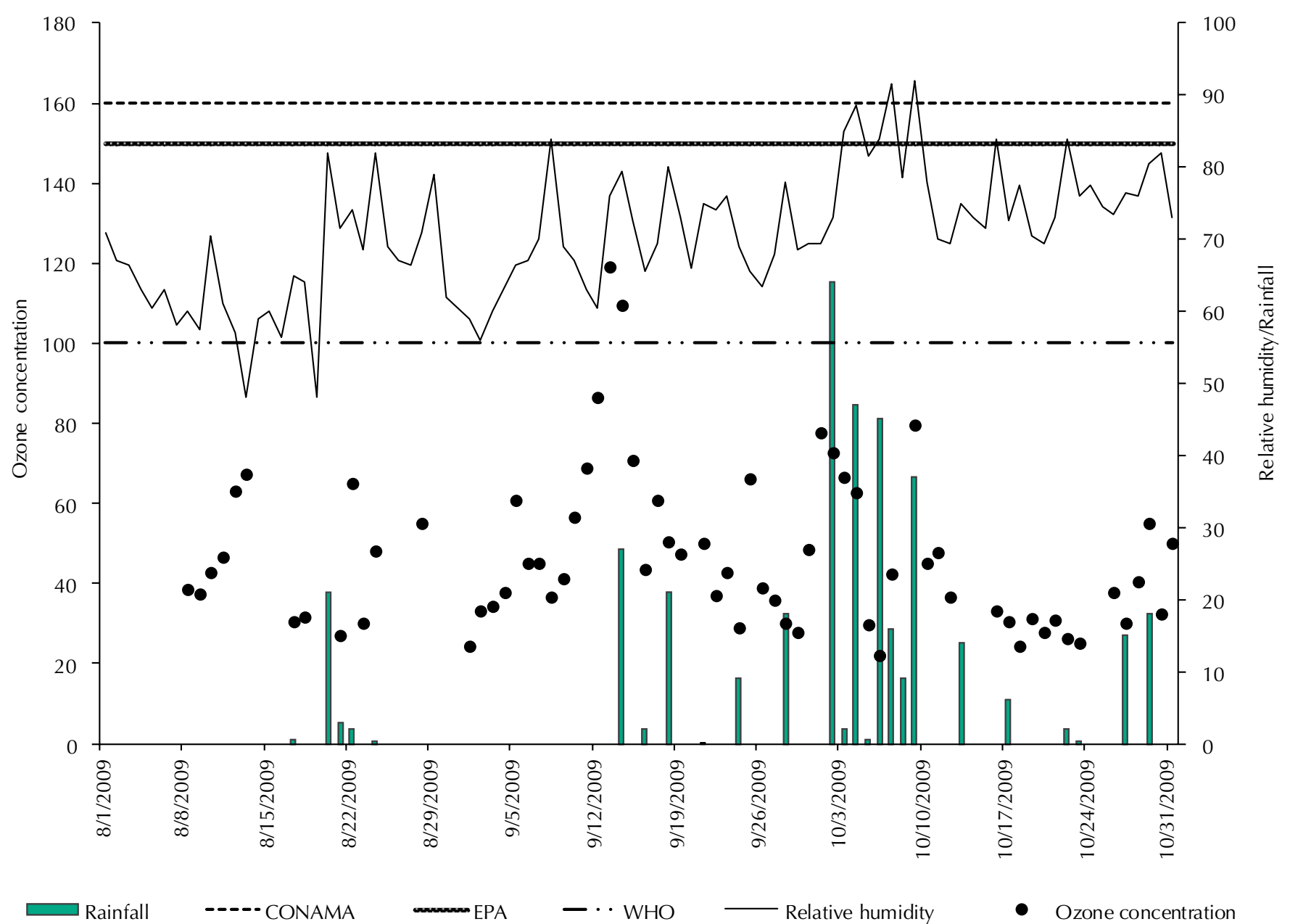

CONAMA: National Environment Council; EPA: Environmental Protection Agency; WHO: World Health Organization; $\mathrm{O}_{3}$ : ozone; $\mathrm{PM}_{2.5}$ : fine particulate matter

Figure 1. Ozone concentration $\left(\mu \mathrm{g} / \mathrm{m}^{3}\right)$ variations according to the average of the eight hours with the greatest concentrations, air quality standards for $\mathrm{O}_{3}$ according to the EPA, CONAMA and WHO, relative humidity (\%), and rainfall (mm/d). Rio Branco, AC, Northern Brazil, period from August to October, 2009. 
The potential average dose of $\mathrm{O}_{3}$ was higher than that of the $\mathrm{PM}_{2.5}$ dose. The doses differed depending on age. Schoolchildren aged six to eight years inhaled a higher potential average dose than those aged nine to 14 years for exposure both to $\mathrm{O}_{3}$ and $\mathrm{PM}_{2.5}$. The comparison between sexes showed statistically significant differences only for exposure to $\mathrm{O}_{3}(\mathrm{p}=0.008)$. The differences between children with and without asthma were significant for exposures to $\mathrm{O}_{3}$ and $\mathrm{PM}_{2.5}$. Among normal-weight schoolchildren, we estimated an average potential dose for $\mathrm{O}_{3}$ and $\mathrm{PM}_{2.5}$ exposure. Both exposure doses significantly differed between normal-weight and overweight schoolchildren (Table 2).

Based on the estimated reference RfD dose of $1.03 \mu \mathrm{g} / \mathrm{kg}$.day of $\mathrm{O}_{3}$ and $1.14 \mu \mathrm{g} / \mathrm{kg}$.day of $\mathrm{PM}_{2.5}$, we estimated toxicological risks by the ratio between average potential doses and RfD.

Regarding $\mathrm{O}_{3}$ exposure, 95,0\% of schoolchildren exposed to this pollutant had risk quotients above 1, which means a toxicological risk of exposure to this pollutant. For $\mathrm{PM}_{25}$, we did not find any toxicological risk for children arising from exposure to this pollutant (Figure 3).

Children aged six to eight years had a risk quotient three times higher than the reference dose $(\mathrm{RQ}=3.03 ; 95 \% \mathrm{CI} 2.93-3.13)$. Children labeled as asthmatic and healthy were also at high risk for exposure to $\mathrm{O}_{3}, \mathrm{RQ}=2.91(95 \% \mathrm{CI} 2.78-3.03)$ and $\mathrm{RQ}=2.77$ (95\%CI 2.66-2.88), respectively.

The variables $\mathrm{O}_{3}$ and $\mathrm{PM}_{2.5}$ concentration were the ones most strongly correlated with the potential intake dose $(r=0.38$ and $r=0.68$, respectively). The variable weight was negatively related to the average potential dose, for both $\mathrm{O}_{3}(\mathrm{r}=-0.29)$ and $\mathrm{PM}_{2.5}(\mathrm{r}=-0.12)$.

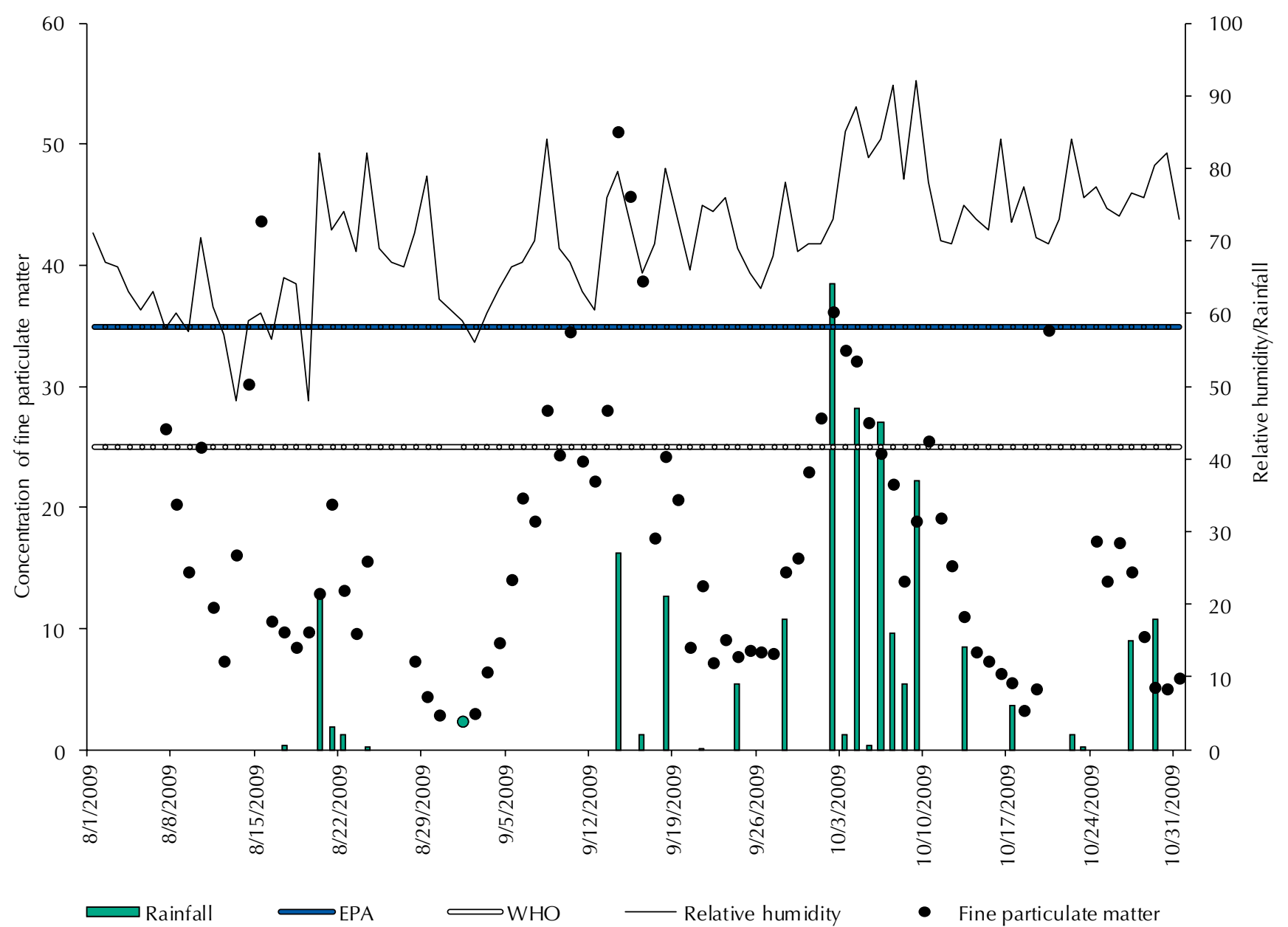

EPA: Environmental Protection Agency; WHO: World Health Organization; $\mathrm{O}_{3}$ : ozone; $\mathrm{PM}_{2.5}$ : fine particulate matter

Figure 2. Average daily $\mathrm{PM}_{2.5}$ concentration variation, air quality standards for $\mathrm{PM}_{2.5}$ according to the EPA and WHO, relative humidity (\%), and rainfall (mm/d). Rio Branco, AC, Northern Brazil, period from August to October, 2009. 
Table 2. Estimated potential intake doses of $\mathrm{O}_{3}$ and $\mathrm{PM}_{2,5}$ among schoolchildren, for an average of the eight hours with the highest $\mathrm{O}_{3}$ concentration and the average of daily $\mathrm{PM}_{2.5}$ according to age, sex, asthma classification, and BMI. Rio Branco, AC, Northern Brazil, 2009.

\begin{tabular}{|c|c|c|c|c|c|c|c|c|}
\hline \multirow{2}{*}{ Variables } & \multicolumn{4}{|c|}{ Average of eight hours of $\mathrm{O}_{3}$} & \multicolumn{4}{|c|}{ Daily average of $\mathrm{PM}_{2.5}$} \\
\hline & Average & \multicolumn{2}{|c|}{$95 \% \mathrm{Cl}$} & $\frac{p}{0.000}$ & & \multicolumn{2}{|c|}{$95 \% \mathrm{Cl}$} & $\frac{p}{0.000}$ \\
\hline $6-8 y$ & 3.12 & 3.02 & 3.22 & & 1.03 & 0.96 & 1.09 & \\
\hline $9-11 y$ & 2.66 & 2.57 & 2.74 & & 0.87 & 0.82 & 0.93 & \\
\hline $12-14 y$ & 2.53 & 2.45 & 2.61 & & 0.83 & 0.78 & 0.88 & \\
\hline Sex & & & & 0.008 & & & & 0.134 \\
\hline Male & 2.93 & 2.82 & 3.05 & & 0.96 & 0.89 & 1.03 & \\
\hline Female & 2.75 & 2.64 & 2.85 & & 0.90 & 0.84 & 0.96 & \\
\hline Asthma & & & & 0.020 & & & & 0.012 \\
\hline Yes & 3.00 & 2.86 & 3.13 & & 1.04 & 0.97 & 1.11 & \\
\hline No & 2.80 & 2.69 & 2.90 & & 0.92 & 0.85 & 0.98 & \\
\hline BMI & & & & 0.000 & & & & 0.000 \\
\hline Healthy & 2.85 & 2.74 & 2.96 & & 0.94 & 0.84 & 1.00 & \\
\hline Overweight & 2.27 & 2.20 & 2.34 & & 0.74 & 0.70 & 0.79 & \\
\hline \multicolumn{9}{|l|}{ Total } \\
\hline All children & 2.83 & 2.72 & 2.94 & & 0.93 & 0.86 & 0.99 & \\
\hline
\end{tabular}

BMI: body mass index; $\mathrm{O}_{3}$ : ozone; $\mathrm{PM}_{2.5}$ : fine particulate matter.

Ozone

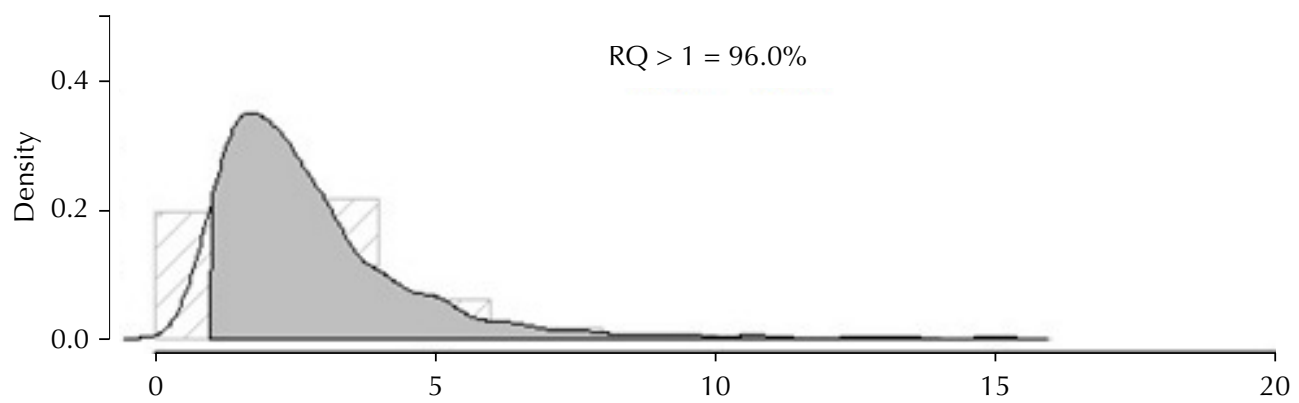

Particulate Matter

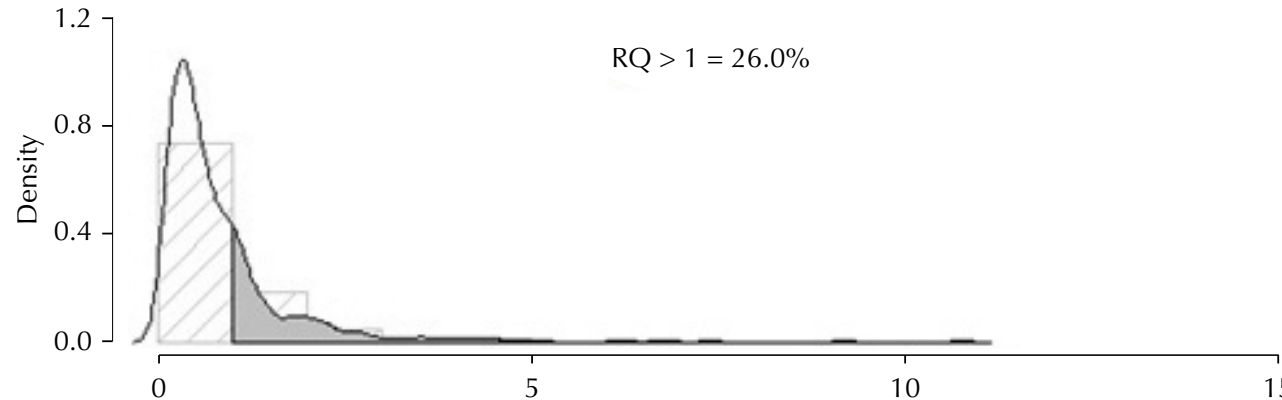

RQ: risk quotient

Figure 3. Distribution of toxicological risk probability for exposure to $\mathrm{O}_{3}$ and $\mathrm{PM}_{2.5}$. Rio Branco, $\mathrm{AC}$ Northern Brazil, 2009.

\section{DISCUSSION}

We verified that schoolchildren aged six to 14 years experienced toxicological risks for $\mathrm{O}_{3}$ from biomass burning in 2009, in the "arch of deforestation", located in Rio Branco. 
We did not find health risks for children exposed to $\mathrm{PM}_{2.5}$. However, during the study the concentrations of this pollutant surpassed the levels prescribed by the EPA and WHO. The highest daily average concentration of $\mathrm{PM}_{2.5}$, measured on September 14, 2009, was $46.0 \%$ higher than the air quality standard prescribed by the EPA, which is $35 \mu \mathrm{g} / \mathrm{m}^{3 \mathrm{i}}$.

Our results were similar to a study conducted in Mexico, which also showed that toxicological risk to the chemical components of $\mathrm{PM}_{2.5}$ was 1.81 for children aged between 6-12 years, but no risk was observed when each chemical component was individually analyzed ${ }^{5}$. However, although any toxicological risk for $\mathrm{PM}_{2.5}$ was observed, exposed individuals may experience non-observable health effects caused by exposure to particulate matter. Several international epidemiological studies showed harmful effects associated with even low concentrations of $\mathrm{PM}_{2.5}$. The doses of exposure were lower than those estimated in Rio Branco during the 2009 dry season ${ }^{15}$. Potential health effects depend on the multi-element composition of particulate matter and its aerodynamic characteristics, its capacity for reaction with other elements or compounds, persistence in the environment, transportation capacity across long distances, exposure time, local climate conditions, and human susceptibility, with several possible impacts on human health ${ }^{3,13,15}$.

Oliveira et al. ${ }^{14}$ found results different from ours. The authors conducted a similar study in which the source of pollutant emissions was sugarcane burning in the city of Tangará da Serra, Mato Grosso state, also within the Amazon biome. The authors found a toxicological risk for $\mathrm{PM}_{2.5}$ of 2.07 in the dry season of the region among children aged six to 14 years. Those results point to possible differentiation in the chemical composition of particulate matter, among other properties of $\mathrm{PM}_{2.5}$.

Even though both studies used the same methodology, the reference concentration for particles released from diesel combustion applied by Oliveira et al. ${ }^{14}$ was lower than the $\mathrm{PM}_{2.5}$ NOAEL applied in this study $\left(5.0 \mu \mathrm{g} / \mathrm{m}^{3}\right.$ and $5.8 \mu \mathrm{g} / \mathrm{m}^{3}$, respectively). However, even using the same reference concentration as Oliveira et al. ${ }^{14}$, the toxicological risk in our study would not be $>1$ for $\mathrm{PM}_{2.5}$. Furthermore, the average $\mathrm{PM}_{2.5}$ concentrations were 2.5 times higher in Tangará da Serra compared with Rio Branco, which could explain the different findings.

The pollutant concentration is a major factor in determining the toxicological risk, since the risk is strongly related with the potential average dose inhaled by schoolchildren exposed to $\mathrm{O}_{3}$ and $\mathrm{PM}_{2.5}$. Therefore, the variable pollutant concentration had the greatest influence in the sensitivity analysis over potential intake doses in both studies.

It is currently understood that, according to the $\mathrm{EPA}^{12}$, the use of NOAEL for $\mathrm{PM}_{2.5}$ is more appropriate because it is specific $\mathrm{PM}_{2.5}$. Although there is no research similar to ours addressing children's exposure to $\mathrm{O}_{3}$, a study showed the association between the breathable dose of an individual exposed to $\mathrm{O}_{3}$ and changes in pulmonary function for different levels and exposure duration ${ }^{12}$.

In Rio Branco, $\mathrm{O}_{3}$ reached maximum levels of $119.4 \mu \mathrm{g} / \mathrm{m}^{3}$, which coincided with the scarce rainfall in the period. Rainfall can increase $\mathrm{O}_{3}$ levels because it transfers $\mathrm{NO}_{2}$, an important $\mathrm{O}_{3}$ precursor, closer to the surface, increasing $\mathrm{NO}_{2}$ levels and consequently $\mathrm{O}_{3}$ formation reactions ${ }^{6}$. Another factor that favors the formation of $\mathrm{O}_{3}$ in Rio Branco is the extension of its forests: approximately $87.0 \%$ of its territory still has exuberant forests. Ozone is typically formed when precursors from combustion emissions, such as $\mathrm{NO}_{\mathrm{x}}$, reach an area with abundant volatile organic compounds (VOC) and solar radiation. The VOC in the Brazilian Amazon are abundantly available in forest areas where vegetation is the greatest natural source ${ }^{6}$.

Even if Rio Branco does not have many slash-and-burns like other regions of the Amazon, its population may be subject to a large amount of $\mathrm{O}_{3}$ precursor pollutants from other states such as Rondonia and Mato Grosso ${ }^{4}$. 
Schoolchildren aged six to eight years incorporated the highest average potential doses of $\mathrm{O}_{3}$ and consequently experienced highest toxicological risk, with $20.0 \%$ higher risk of effects on health when compared with 9-11 and 12-14 age groups. Because of their physiological growth and pulmonary development, children are vulnerable to environmental pollutants ${ }^{\mathrm{a}}$. In this study, $19.0 \%$ of children were classified as asthmatic, according to the International Study of

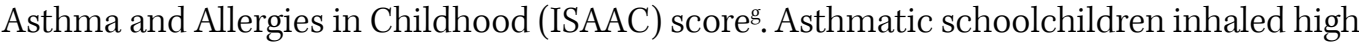
average potential doses for $\mathrm{O}_{3}$ exposure. There is evidence in the literature that asthmatic children are more vulnerable to adverse effects caused by exposure to $\mathrm{O}_{3}$, following the hypothesis that inhaling high doses of $\mathrm{O}_{3}$ could lead to airway hyperactivity and inflammation, and that this would make individuals with asthma more likely to experience pulmonary obstructions ${ }^{11}$. In a cohort study, the incidence of new asthma diagnoses increased among children living in regions with high $\mathrm{O}_{3}$ concentrations ${ }^{11}$.

The toxicological risk for exposure to $\mathrm{O}_{3}$ in schoolchildren evidenced in our study indicates that air quality standards prescribed by the EPA and WHO do not protect human health from exposure to this pollutant. The $\mathrm{O}_{3}$ LOAEL used in the present study corresponds to the lowest dose of the pollutant that can cause an adverse effect on human health, including vulnerable subgroups, during a certain exposure time. It is eight times lower than the level established as the air standard quality for $\mathrm{O}_{3}$ in Brazil by Conselho Nacional do Meio Ambiente (CONAMA - National Council for the Environment) ${ }^{j}$, which is $160 \mu \mathrm{g} / \mathrm{m}^{3}$. This is the maximum tolerable concentration of $\mathrm{O}_{3}$ during an average one-hour period. The CONAMA is responsible for setting air quality standards for pollutants in Brazil. Its latest update in environmental legislation occurred in 1990, which we consider out of date.

Limitations of this study include insufficient coverage of the population exposed to slashand-burns by air quality monitoring networks across longer periods, which would allow for evaluating a trend of exposure to the main pollutants released by burns in the region. Another limitation is the quality of healthcare data, their standardization, and accessibility. Lack of agreement in environmental agencies on the reference concentration for $\mathrm{O}_{3}$ is also associated with the lack of continuous air quality monitoring networks. Children's inhalation rate was obtained from an international study, since there are no similar studies in Brazil providing measurement parameters for individuals' daily inhalation rate according to age group, sex, and BMI. Finally, it was also difficult to acquire accurate $\mathrm{PM}_{2.5}$ measurements, which were obtained from the daily ratio between $\mathrm{PM}_{2.5(\mathrm{AFG})} / \mathrm{PM}_{10(\mathrm{AFG})}$ applied to real time $\mathrm{PM}_{10 \text { (твOM) }}$ mass measurements.

We conclude that schoolchildren residing in Rio Branco were exposed to high doses of $\mathrm{O}_{3}$ during the dry season of the region, and this poses toxicological risk. Schoolchildren aged six to eight years incorporated the highest average potential doses of $\mathrm{O}_{3}$ and consequently experienced the highest toxicological risk.

\section{REFERENCES}

1. Anenberg SC, Horowitz LW, Tong DQ, West JJ. An estimate of the global burden of anthropogenic ozone and fine particulate matter on premature human mortality using atmospheric modeling. Environ Health Perspect. 2010;118(9):1189-95. DOI:10.1289/ehp.0901220

2. Brochu P; Ducré-Robitaille J; Brodeur J. Physiological daily inhalation rates for free-living individuals aged 2.6 months to 96 years based on doubly labeled water measurements: comparison with time-activity-ventilation and metabolic energy conversion estimates. Hum Ecol Risk Assess. 2006;12(4):736-61. DOI:10.1080/10807030600801626

'Conselho Nacional do Meio Ambiente. Resolução n ${ }^{\circ}$, de 28 de junho de 1990. Padrões de qualidade do ar. Diario Oficial Uniao. 1990 Ago 28.
3. Collins JF, Alexeeff GV, Lewis DC, Dodge DE, Marty MA, Parker TR et al. Development of acute inhalation reference exposure levels (RELs) to protect the public from predictable excursions of airborne toxicants. J App/ Toxicol. 2004;24(2):155-66. DOI:10.1002/jat.967

4. Davidson EA, Araújo AC, Artaxo P, Balch JK, Brown IF, Bustamante MMC et al. The Amazon basin in transition. Nature. 2012;481:321-8. DOI:10.1038/nature10717 
5. Díaz RV, Rosa Dominguez E. Health risk by inhalation of $P M_{2.5}$ in the metropolitan zone of the City of Mexico. Ecotoxicol Environ Saf. 2009;72(3):866-71. DOI:10.1016/j.ecoenv.2008.09.014

6. Freitas SR, Longo KM, Rodrigues LF. Modelagem numérica da composição química da atmosfera e seus impactos no tempo, clima e qualidade do ar. Rev Bras Meteorol. 2009;24(2):188-207. DOI:10.1590/S0102-77862009000200008

7. Hazucha MJ, Folinsbee LJ, Bromberg PA. Distribution and reproducibility of spirometric response to ozone by gender and age. J Appl Physiol. 2003;95:1917-25. DOI:10.1152/ japplphysiol.00490.2003

8. Ignotti E, Hacon SS, Junger WL, Mourão D, Longo K, Freitas S et al. Air pollution and hospital admissions for respiratory diseases in the subequatorial Amazon: a time series approach. Cad Saude Publica. 2010;26(4):747-61.

9. Ignotti E, Valente JG, Longo KM, Freitas SR, Hacon SS, Artaxo Neto P. Impact on human health of particulate matter emitted from burnings in the Brazilian Amazon region. Rev Saude Publica. 2010;44(1):121-30. DOI:10.1590/S0034-89102010000100013

10. Jacobson LSV, Hacon SS, Castro HA, Ignotti E, Artaxo P, Leon ACMP. Association between fine particulate matter and the peak expiratory flow of school children in the Brazilian subequatorial Amazon: a panel study. Environ Res. 2012;117:27-35. DOI:10.1016/j.envres.2012.05.006

11. McConnell R, Berhane K, Gilliland F, London SJ, Islam T, Gauderman WJ et al. Asthma in exercising children exposed to ozone: a cohort study. Lancet. 2002;359(9304):386-91. DOI:10.1016/S0140-6736(02)07597-9

12. McDonnell WF 3rd, Chapman RS, Leigh MW, Strope GL, Collier AM. Respiratory responses of vigorously exercising children to 0.12 ppm ozone exposure. Am Rev Respir Dis. 1985;132(4):875-9.

13. Nunes KVR, Ignotti E, Hacon S. Circulatory disease mortality rates in the elderly and exposure to PM2.5 generated by biomass burning in the Brazilian Amazon in 2005. Cad Saude Publica. 2013;29(3):589-98. DOI:10.1590/S0102-311X2013000300016

14. Oliveira BFA, Ignotti E, Artaxo P, Saldiva PHN, Junger WL, Hacon S. Risk assessment of $\mathrm{PM}_{2.5}$ to child residents in Brazilian Amazon region with biofuel production. Environ Health. 2012;11:64. DOI:10.1186/1476-069X-11-64

15. Pope CA 3rd, Burnett RT, Thun MJ, Calle EE, Krewski D, Ito K, Thurston GD. Lung cancer, cardiopulmonary mortality, and long-term exposure to fine particulate air pollution. JAMA. 2002;287(9):1132-41. DOI:10.1001/jama.287.9.1132

16. U.S. Environmental Protection Agency. Review of the national ambient air quality standards for ozone: policy assessment of scientific and technical information. North Carolina: U.S. Environmental Protection Agency; 2007. (EPA-452/R-07-007).

Funding: Brazilian Ministry of Health (Process 33781.0550001/07-050).

Author's Contribution: Development and planning of the study: PRSS, EI. Data collection: FM, PA. Data analysis and interpretation: PRSS, EI, FM, BFAO, PA, WLJ. Elaboration or composition of the manuscript: PRSS, EI. Critical review of the manuscript: PRSS, EI, SH. Final approval: PRSS, EI, SH, BFAO, WLJ, FM, PA.

Conflict of Interest: The authors declare no conflict of interest. 